\title{
Effects of Standardized Extracts of St. John's Wort on the Single-Unit Activity of Serotonergic Dorsal Raphe Neurons in Awake Cats: Comparisons with Fluoxetine and Sertraline
}

Casimir A. Fornal, Ph.D., Christine W. Metzler, M.S., Christian Mirescu, B.S., Susan K. Stein, M.S., and Barry L. Jacobs, Ph.D.

St. John's wort is widely used as an herbal remedy for depression. Although its mechanism of action remains unknown, some evidence suggests that St. John's wort might act via brain serotonin (e.g., as a serotonin reuptake inhibitor). To determine whether St. John's wort affects the central serotonergic system, we monitored the discharge rate of serotonin-containing neurons in the dorsal raphe nucleus of awake cats following systemic administration of two clinical preparations of St. John's wort, Jarsin ${ }^{\circledR} 300$ (15-600 mg/kg, p.o.) and Hyperforat巴 (0.5-4.0 ml, i.v.). Both preparations were found to have no effect on neuronal activity. This contrasts sharply with the action of fluoxetine and sertraline (2 $\mathrm{mg} / \mathrm{kg}$, p.o.), two selective serotonin reuptake inhibitors (SSRIs), which markedly depressed neuronal activity by increasing the synaptic availability of serotonin at inhibitory somatodendritic $5-\mathrm{HT}_{1 \mathrm{~A}}$ autoreceptors. The failure of St. John's wort to depress neuronal activity cannot be attributed to an impairment of the $5-\mathrm{HT}_{1 \mathrm{~A}}$ autoreceptor mechanism, since pretreatment with Jarsin $300(300 \mathrm{mg} / \mathrm{kg}$, p.o.) did not alter the responsiveness of serotonergic neurons to the $5-\mathrm{HT}_{1 \mathrm{~A}}$ agonist 8-hydroxy-2-(di-n-propylamino)tetralin (8-OHDPAT) $(10 \mu \mathrm{g} / \mathrm{kg}$, i.v. $)$. Overall, these findings indicate that the mode of action of St. John's wort is different from that of conventional antidepressant drugs, which elevate brain serotonin and evoke negative feedback control of serotonergic neurons.

[Neuropsychopharmacology 25:858-870, 2001] (C) 2001 American College of Neuropsychopharmacology. Published by Elsevier Science Inc.
From the Program in Neuroscience, Department of Psychology, Princeton University, Princeton, NJ 08544

Address correspondence to: Casimir A. Fornal, Department of Psychology, Green Hall, Princeton University, Princeton, NJ 08544. Tel.: (609) 258-6606; Fax: (609) 258-1113; E-mail: fornal@princeton.edu

Received December 19, 2000; revised May 22, 2001; accepted June 4, 2001.

Online publication: 6/5/01 at www.acnp.org/citations/ Npp060501129.
KEY WORDS: Hypericum perforatum; LI 160; Antidepressants; Selective serotonin reuptake inhibitors; Dorsal raphe nucleus; 5-hydroxytryptamine (serotonin); Electrophysiology

The medicinal plant Hypericum perforatum L., commonly known as St. John's wort, appears to be an effective antidepressant with few side effects (Hippius 1998; Wheatley 1998; Vitiello 1999). In Germany, where extracts of the plant are licensed as a medication, St. John's wort or hypericum is used more extensively than 
conventional antidepressant drugs for the treatment of mild to moderate depression, the most prevalent forms of this disorder. The antidepressant efficacy of hypericum extracts has been documented in a number of small, double-blind, placebo-controlled studies, conducted mainly in Europe (Volz 1997). A widely cited meta-analysis of 23 randomized clinical trials concluded that hypericum extracts were significantly superior to placebo and comparable to tricyclic antidepressant drugs in alleviating depressive symptoms (Linde et al. 1996). Since the publication of that influential report, several other systematic reviews (and one metaanalysis) have appeared which further support the antidepressant efficacy of hypericum (Josey and Tackett 1999; Kim et al. 1999; Stevinson and Ernst 1999; Gaster and Holroyd 2000). Furthermore, in comparison with other antidepressants, St. John's wort is well tolerated and has a low side effect profile (Linde et al. 1996; Ernst et al. 1998). Due to the growing popularity of St. John's wort in the United States, the National Institutes of Health (NIH) has recently sponsored a large, multicenter clinical trial to assess the long-term efficacy and safety of St. John's wort in treating severely depressed patients (Bunk 1999; Vitiello 1999). The findings of this clinical study should be made available sometime in the year 2001 and will be important for the future development of St. John's wort as an alternative to standard antidepressant agents.

Despite its widespread use, the active constituents and mechanism of antidepressant action of St. John's wort remain largely unknown (Bennett et al. 1998; Nathan 1999). A number of studies have shown that crude hypericum preparations and some of the constituents can inhibit monoamine oxidase (MAO) activity in vitro (Demisch et al. 1989; Thiede and Walper 1994; Cott 1997; Müller et al. 1997). However, the clinical relevance of this pharmacological effect is questionable, since it occurs only at high concentrations and has not been observed in vivo (Bladt and Wagner 1994; Yu 2000). More recent studies have focused on the capacity of St. John's wort to inhibit the uptake of brain monoamines, particularly serotonin (Müller et al. 1997, 1998; Neary and Bu 1999). Perovic and Müller (1995) were the first to report that a crude hypericum extract inhibited the uptake of serotonin in rat cortical synaptosomes at relatively low concentrations and conclude that the antidepressant activity of St. John's wort is due to this action. Hypericum has also been shown to inhibit the synaptosomal uptake of dopamine and norepinephrine, at concentrations similar to those found to inhibit the uptake of serotonin (Müller et al. 1997). In subsequent studies, the chemical substance hyperforin was identified as one of the major uptake-inhibiting components of St. John's wort (Müller et al. 1998; Chatterjee et al. 1998; Singer et al. 1999). The content of this substance has recently been associated with the clinical antidepressant action of St. John's wort (Laakmann et al. 1998), suggesting that hyperforin is at least partially responsible for the antidepressant properties of the herb. Other evidence suggest that hypericum extracts may enhance the release of serotonin from presynaptic stores (Gobbi et al. 1999). Neurochemical studies have shown that St. John's wort increases serotonin metabolism and/or turnover in various brain regions (Calapai et al. 1999; Yu 2000). Finally, it has been hypothesized that the clinical efficacy of St. John's wort may result from a combination of several mechanisms, with each one unable to account for the therapeutic effect alone (see Bennett et al. 1998). Thus, it is possible that St. John's wort may enhance serotonin neurotransmission through its weak inhibition of MAO, blockade of serotonin uptake, and/or via a serotonin releasing action. In the present study, we examined the effect of St. John's wort on the firing rate of serotonin-containing neurons in the dorsal raphe nucleus, which provide the major ascending serotonergic input to the forebrain (Jacobs and Azmitia 1992). These neurons have been implicated in the pathophysiology of depression and in the mechanism of action of various antidepressant drugs (Blier and de Montigny 1994; Maes and Meltzer 1995). Furthermore, because St. John's wort is thought to act primarily via inhibition of serotonin uptake, we compared the effects of two hypericum extracts with those of fluoxetine and sertraline, two chemically-distinct SSRIs, widely used in the treatment of major depression.

Previous studies have shown that the discharge rate of serotonergic neurons is highly sensitive to drugs acting on the central serotonergic system. Agents which increase the synaptic availability of serotonin in the brain (e.g., serotonin precursors, releasers, uptake blockers, and MAO inhibitors) produce a compensatory decrease in neuronal activity, by activating somatodendritic $5-\mathrm{HT}_{1 \mathrm{~A}}$ autoreceptors on serotonergic neurons located within the midbrain raphe (Aghajanian and Wang 1978; Aghajanian and VanderMaelen 1986; Gartside et al. 1997). This region may be a selective target for serotonergic antidepressant drugs (Artigas 1993). Therefore, we reasoned that if St. John's wort acts by enhancing brain serotonin, it should produce a reduction of serotonergic neuronal activity, like all other antidepressant drugs acting via serotonin. However, it is also possible that St. John's wort may enhance serotonin neurotransmission through a novel mechanism, for example, by increasing the firing rate of brain serotonergic neurons. The present study sought to determine which, if any, of these possible actions can be attributed to St. John's wort.

Because the chemical composition, quality, and purity of St. John's wort has been shown to vary considerably across different preparations (Constantine and Karchesy 1998; Kurth and Spreemann 1998; Liu et al. 2000), results obtained with one may not generalize to others. Since most of the clinical and experimental stud- 
ies on St. John's wort have been conducted with a particular hydromethanolic extract called LI 160, which is contained in Jarsin ${ }^{\circledR} 300$, we selected this preparation for our studies. Jarsin ${ }^{\circledR} 300$ is the most widely prescribed hypericum extract in Germany (Müller and Kasper 1997; Volz 1997), with proven therapeutic efficacy (Linde et al. 1996; Volz 1997). (This preparation is identical to Kira ${ }^{\mathrm{TM}}$ sold in the U.S. and the one selected for study by NIH.) In addition, we tested the effects of Hyperforat ${ }^{\circledR}$, a liquid preparation of St. John's wort, which can be administered intravenously, thus bypassing the slow absorption of St. John's wort from the gastrointestinal tract. To our knowledge, this is the first electrophysiological study of the effects of clinically used hypericum extracts on brain serotonergic neurons.

\section{MATERIALS AND METHODS}

\section{Animals}

Adult male cats (2.5-5.0 kg body weight) were housed individually in a temperature-controlled $\left(22 \pm 1^{\circ} \mathrm{C}\right)$ colony maintained on a 14:10-h light-dark cycle (lights on at 7 A.M.). Food (Purina cat chow) and tap water were available ad libitum unless otherwise noted. All cats were cared for and used in strict accordance to the PHS Guide for the Care and Use of Laboratory Animals. All procedures were reviewed and approved by the Institutional Animal Care and Use Committee of Princeton University.

\section{Surgical Procedures}

Cats, fasted overnight, were pretreated with atropine sulfate $(0.05 \mathrm{mg} / \mathrm{kg}$, s.c.) and buprenorphine $(0.01 \mathrm{mg} /$ $\mathrm{kg}$, s.c.) and tranquilized with acepromazine maleate $(0.5 \mathrm{mg} / \mathrm{kg}$, i.m.) and ketamine hydrochloride $(20 \mathrm{mg} /$ $\mathrm{kg}$, i.m.) for preoperative preparation. Prior to placing the cat in a stereotaxic instrument, surgical anesthesia was induced and maintained with pentobarbital sodium, administered to effect via a cephalic vein catheter. Rectal temperature was maintained between 36 and $38^{\circ} \mathrm{C}$ with a heating pad. Under sterile conditions, a microdrive, consisting of two inner stainless steel cannulae ( 23 gauge) separated by $1 \mathrm{~mm}$, that can be lowered through two guide cannulae (19 gauge), was stereotaxically implanted towards the dorsal raphe nucleus at an angle of $40^{\circ}$ posterior to the vertical. After the microdrive was fixed to the skull, microelectrode bundles were then stereotaxically inserted through the inner cannulae, so that their tips were positioned $1 \mathrm{~mm}$ above the dorsal raphe nucleus. Stereotaxic coordinates for the anterior bundle were: posterior, $1.5 \mathrm{~mm}$; lateral, 0 $\mathrm{mm}$; and horizontal, $+1.0 \mathrm{~mm}$ (Snider and Niemer 1970). Each bundle consisted of three 32- $\mu \mathrm{m}$ and four $64-\mu \mathrm{m}$ diameter Formvar-insulated nichrome wires.
Additionally, electrodes for recording cortical electroencephalogram (EEG), electrooculogram (EOG), and nuchal electromyogram (EMG) were implanted. The leads from all electrodes were soldered to a 25-pin connector, and the entire apparatus was anchored to the skull with dental acrylic. Cats were removed from the stereotaxic apparatus and then implanted with an indwelling jugular catheter (Tygon, $0.18 \mathrm{~mm}$ o.d.) for remote drug injections. The distal end of the catheter, equipped with a three-way stopcock, was capped and cemented to the implant. Cats were allowed a minimum of two weeks to recover from surgery before experiments were initiated.

\section{Electrophysiological Recordings}

Electrical potentials were recorded from each cat using a counterweighted low-noise cable system and 24-channel slip ring assembly. Extracellular microelectrode potentials were amplified (Grass 7P511 ac preamp), filtered (band-pass $0.1-3.0 \mathrm{kHz}$ ), and monitored continuously on a storage oscilloscope and on a computer. A second microelectrode in the same bundle served as an indifferent electrode. Single-unit activity was separated from background noise with a time-amplitude window discriminator. The output of the discriminator was used to obtain an on-line record of cell discharge through a speaker, an electronic counter, and a polygraph (Grass model 7C). To ensure that recordings were made from the same cell throughout the experiment, the waveform of each action potential was displayed continuously (Data Wave Technologies software). The cortical EEG, EOG, and EMG were recorded simultaneously on the polygraph.

All recording experiments were conducted in an electrically shielded, sound-attenuating chamber $(65 \mathrm{x}$ $65 \times 95 \mathrm{~cm}$ high), illuminated by incandescent lighting. A transparent Plexiglas front door allowed for remote closed-circuit television monitoring of the animal. Each animal was habituated daily to the recording chamber over a 2-week period following recovery from surgery. After habituation, the microelectrode bundles were slowly advanced $(\sim 40 \mu \mathrm{m})$ through the target nucleus, until stable single unit recordings characteristic of serotonergic neurons were encountered. Only those recordings that displayed a signal-to-noise ratio of at least 3:1 were used in experiments. Such neurons typically can be recorded for several hours and often for several days.

\section{Neuronal Identification}

Serotonergic neurons were initially identified on-line according to previously established criteria (Fornal and Jacobs 1988): 1) slow and highly regular discharge activity ( $\sim 1-4$ spikes/sec) during quiet waking; 2 ) biphasic action potentials of relatively long duration $(\geq 2$ 
msec); and 3) complete or nearly complete suppression of spontaneous activity during rapid-eye-movement (REM) sleep. The neurochemical identity of these neurons was further established pharmacologically by determining their response to systemic administration of the $5-\mathrm{HT}_{1 \mathrm{~A}}$ receptor agonist $8-\mathrm{OH}-\mathrm{DPAT}(10 \mu \mathrm{g} / \mathrm{kg}$, i.v. or $100 \mu \mathrm{g} / \mathrm{kg}$, s.c.), which strongly inhibits the spontaneous discharge of brain serotonergic neurons (Sprouse and Aghajanian 1986). Finally, post-mortem localization of recording sites to the dorsal raphe nucleus was verified histologically for all neurons recorded.

\section{Drug Administration}

Single-unit activity was recorded before and after systemic administration of St. John's wort and other test compounds. To assess the effect of Jarsin ${ }^{\circledR} 300$ on spontaneous neuronal activity, single doses $(15-600 \mathrm{mg} / \mathrm{kg}$, p.o.) were administered as whole and/or divided tablets, depending upon the dose and weight of the cat. For comparison purposes, fluoxetine and sertraline were administered orally in gelatin capsules (size 0). Empty gelatin capsules served as the control for these experiments. Prior to oral dosing, food was withheld for two hours. To examine the role of $5-\mathrm{HT}_{1 \mathrm{~A}}$ autoreceptors in the inhibitory action of fluoxetine and sertraline, the selective $5-\mathrm{HT}_{1 \mathrm{~A}}$ receptor antagonist $\mathrm{N}$-[2-[4-(2-methoxyphenyl)-1-piperazinyl]ethyl]-N-(2-pyridinyl) cyclohexanecarboxamide (WAY-100635) $(0.2 \mathrm{mg} / \mathrm{kg}$, s.c.) was administered 24 hours after each SSRI, at a time when neuronal activity was still markedly suppressed. For the chronic St. John's wort trials, Jarsin ${ }^{\circledR} 300$ (150 mg/ $\mathrm{kg}$, p.o.) was administered twice daily, at 12 -h intervals for up to 21 days, while recording the same cell. Neuronal activity was assessed each morning ( $\sim 10$ A.M.) for 10-20 min, immediately prior to oral dosing. For these experiments, food was not withheld prior to treatment. To determine the dose-response relationship for Hyperforat ${ }^{\circledR}$ on neuronal activity, Hyperforat ${ }^{\circledR}$ was administered intravenously in a cumulative fashion at 5-min intervals, until a total dose of $4 \mathrm{ml}$ of extract was given. The effect of St. John's wort on the function of 5-HT $1 \mathrm{~A}$ autoreceptors was assessed by examining the response of serotonergic neurons to an intravenous challenge dose of 8 -OH-DPAT $(10 \mu \mathrm{g} / \mathrm{kg})$ before and after administration of Jarsin ${ }^{\circledR} 300$ ( $300 \mathrm{mg} / \mathrm{kg}$, p.o.). Two different pretreatment times of Jarsin ${ }^{\circledR} 300$ were used (3 and $5 \mathrm{~h}$ ). (We have previously shown that inhibitory responses to two consecutive i.v. injections of $8-\mathrm{OH}-$ DPAT are nearly identical (Fornal et al. 1996)). Remote intravenous drug injections were made from an adjacent room via an infusion line connected to the venous catheter. Drugs were loaded into the infusion line and flushed with 1-2 $\mathrm{ml}$ of sterile normal saline over a 5-sec period. Pulse injections of an equivalent volume of sterile saline served as a control. Each acute drug treatment was evaluated in at least four different cats. Animals did not have access to food or water during the recording session.

\section{Data Collection}

Because the activity of serotonergic neurons varies with the level of behavioral arousal (Fornal and Jacobs 1988), firing rate data for the drug experiments were obtained during comparable periods of quiet waking (based on polygraphic and behavioral criteria). For the oral drug administration trials (i.e., Jarsin ${ }^{\circledR} 300$, fluoxetine and sertraline), firing rates were calculated from twelve consecutive 10-sec samples at predefined time intervals and compared to baseline. For the intravenous drug administration trials (i.e., Hyperforat ${ }^{\circledR}$ and 8-OH-DPAT), firing rates were calculated from six consecutive 10-sec samples. The percentage change in firing rate after Hyperforat ${ }^{\circledR}$ was determined by comparing the baseline discharge rate to the mean rate obtained after each successive drug injection.

\section{Drugs}

The two hypericum preparations used in this study were Jarsin ${ }^{\circledR} 300$ (each coated tablet consists of $300 \mathrm{mg}$ dry extract, standardized to $0.3 \%$ hypericin, containing 3-5\% hyperforin; Lichtwer Pharma AG, Berlin, Germany) and Hyperforat ${ }^{\circledR}$ (each ampule contains $1 \mathrm{ml}$ fluid extract, standardized to $0.05 \mathrm{mg}$ hypericin, in physiological saline; Dr. Gustav Klein Arzneipflanzenforschung, Zell am Harmersbach, Germany). Although these extracts are standardized to hypericin (a characteristic reddish-brown pigment in the plant), hypericin is no longer regarded as the major antidepressant component in St. John's wort, but serves as a good indicator of the quality of the preparation nevertheless.

The following drugs were also used: ( \pm )-8-OH-DPAT hydrobromide (Research Biochemicals International, Natick, MA); ( \pm )-fluoxetine hydrochloride (courtesy of Eli Lilly, Indianapolis, IN); sertraline hydrochloride (courtesy of Pfizer, Groton, CT); WAY-100635 trihydrochloride (courtesy of Wyeth Research, Taplow, England). 8-OH-DPAT and WAY-100635 were dissolved in sterile saline and administered in a volume of 0.1 or $0.2 \mathrm{ml} / \mathrm{kg}$ body weight. All drug solutions were prepared fresh immediately before each trial. Dosages of all drugs refer to the chemical form noted.

\section{Histology}

At the completion of the study, the specific location of each recorded neuron was determined. Animals were anesthetized with ketamine hydrochloride $(40 \mathrm{mg} / \mathrm{kg}$, i.m.) and direct anodal current was passed through the recording electrodes $(40 \mu \mathrm{A}$ for $30 \mathrm{sec})$ at sites from 
which acceptable units were recorded. Cats were then overdosed with pentobarbital sodium $(100 \mathrm{mg} / \mathrm{kg}$, i.v.) and perfused intracardially with physiological saline, followed by $10 \%$ formaldehyde (Formalin), and then $5 \%$ potassium ferrocyanide in formaldehyde to produce a Prussian blue reaction. Brains were removed, and $50 \mu \mathrm{m}$-thick frozen sections were cut through the midbrain. Sections were mounted on slides and stained with neutral red which allowed recording sites (blue spots) to be located.

\section{Statistical Analysis}

Data are expressed as means \pm S.E.M. Unit activity was analyzed using a one-way or two-way repeated-measures analysis of variance (ANOVA) and subsequent Student-Newman-Keuls test, or, where appropriate, a paired t-test. In all cases, a probability value $<.05$ was considered statistically significant.

\section{RESULTS}

\section{General Characteristics}

Data reported in this paper were obtained from 44 serotonergic neurons recorded in 17 cats. The mean discharge rate of these neurons during quiet waking was $3.24 \pm 0.12$ spikes/sec. The activity of all cells was strongly suppressed during REM sleep (mean decrease, $94 \pm 3 \% ; \mathrm{n}=44)$ and in response to systemic administration of the $5-\mathrm{HT}_{1 \mathrm{~A}}$ receptor agonist $8-\mathrm{OH}-\mathrm{DPAT}$ (mean decrease, $99 \pm 1 \% ; n=41$ ). Upon histological examination, all cells were found to be localized on, or near, the midline within the dorsal raphe nucleus (Figure 1), where the cell bodies of serotonin-containing neurons are highly concentrated (Jacobs et al. 1984).

\section{Effect of Acute Oral Administration of Jarsin ${ }^{\circledR} 300$}

Figure 2 shows the response of serotonergic dorsal raphe neurons to single oral doses of Jarsin ${ }^{\circledR} 300(15,75$, and $300 \mathrm{mg} / \mathrm{kg}$ ) over a 10-h recording period, and Figure 3 shows the dose-response relationship for Jarsin ${ }^{\circledR} 300$. Administration of Jarsin ${ }^{\circledR} 300$ had no significant effect on the spontaneous activity of serotonergic neurons. The discharge rate of any given cell after Jarsin ${ }^{\circledR} 300$ did not vary more than $14 \%$ below or $31 \%$ above its respective baseline firing rate, which is similar to the variation observed after placebo control.

We also tested a higher dose of Jarsin ${ }^{\circledR} 300(600 \mathrm{mg} /$ $\mathrm{kg}$ ) on the activity of 8 serotonergic dorsal raphe neurons in seven cats. All but one of these cats vomited after Jarsin ${ }^{\circledR} 300$, with latencies ranging approximately 2 to 4 hours from oral dosing. It was clear that these animals did not receive the full hypericum dose, since partially digested tablets were sometimes visible in the

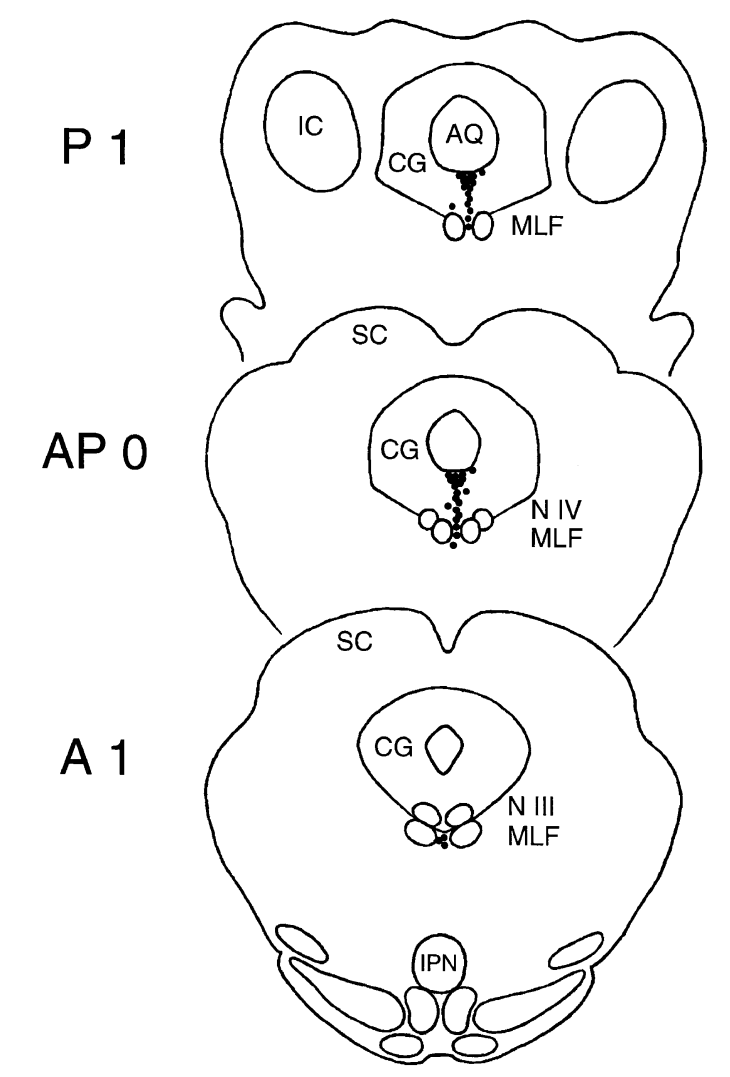

Figure 1. Diagrammatic representation of the location of serotonergic neurons within the dorsal raphe nucleus. Recording sites are depicted as dots in coronal sections of the cat brainstem. Cells were localized on or near the midline, just below the cerebral aqueduct down to the medial longitudinal fasiculus. MLF, medial longitudinal fasiculus; N III, oculomotor nucleus; N IV, trochlear nucleus; SC, superior colliculus; IC, inferior colliculus; $\mathrm{AQ}$, cerebral aqueduct; $\mathrm{CG}$, central gray; IPN, interpeduncular nucleus.

vomitus, stained dark brown due to the presence of the herb. Neuronal activity in these cats was unaffected during the interval prior to emesis and remained unchanged until the experiments were terminated, 2 to 4 hours later. Figure 4 shows polygraph traces of unit activity from the only cat that tolerated the highest dose of Jarsin ${ }^{\circledR} 300(600 \mathrm{mg} / \mathrm{kg})$. This figures illustrates the lack of effect of hypericum extract on both the firing rate and discharge pattern of serotonergic dorsal raphe neurons in general.

\section{Effects of Acute Oral Administration of Fluoxetine and Sertraline}

In contrast to the lack of effect of acute Jarsin ${ }^{\circledR} 300$, oral administration of the SSRIs fluoxetine and sertraline, both at $2 \mathrm{mg} / \mathrm{kg}$, markedly depressed the spontaneous activity of serotonergic dorsal raphe neurons, as shown in Figures 5 and 6. Significant reductions of neuronal 

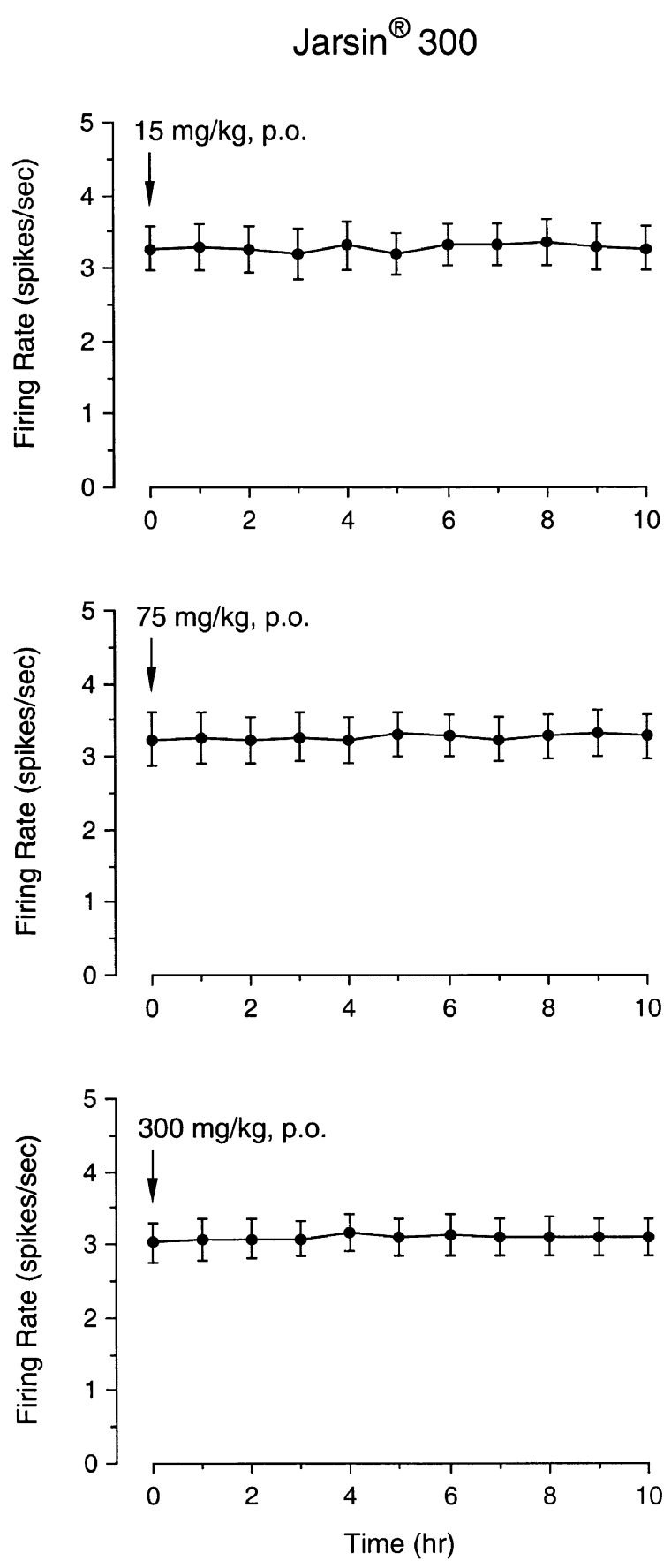

Figure 2. Effect of acute oral administration of Jarsin ${ }^{\circledR} 300$ $(15,75$ and $300 \mathrm{mg} / \mathrm{kg})$ on the spontaneous activity of serotonergic dorsal raphe neurons in awake cats. Values are means \pm S.E.M.; $\mathrm{n}=7$ or 8 cells per group. Arrows denote time of administration. This popular extract of St. John's wort had no appreciable effect on neuronal activity over the 10-h recording period.

activity occurred within 1 to 2 hours after administration and the peak drug effects were reached at approximately four hours. Firing rates were maximally reduced by $91 \pm 5 \%(n=5)$ after fluoxetine and $82 \pm 7 \%$

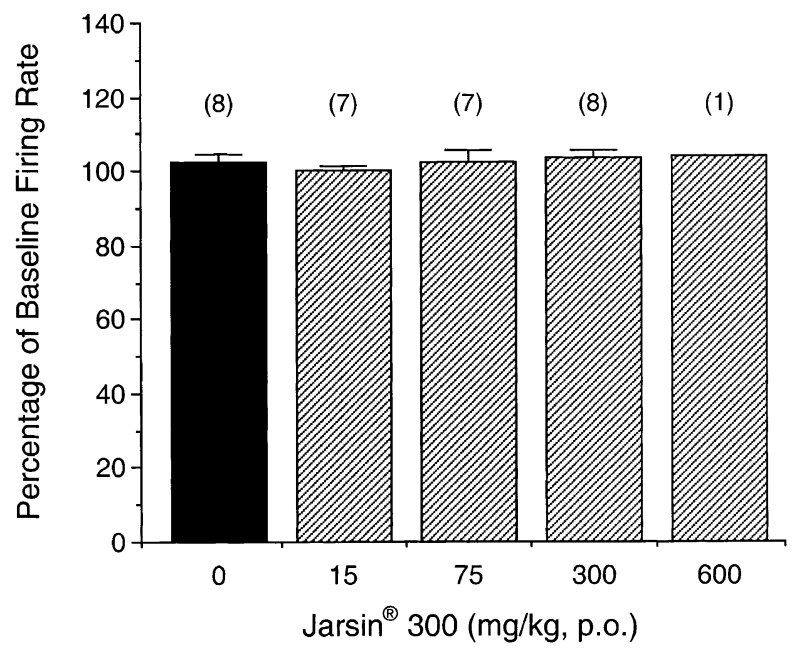

Figure 3. Dose-response curve for the acute effect of Jarsin ${ }^{\circledR} 300$ (15-600 mg/kg, p.o.) on serotonergic dorsal raphe neuronal activity. Values are means \pm S.E.M.; number in parentheses indicate the number of cells tested at each dose. The administration of St. John's wort over a wide range of doses had no significant effect on neuronal activity. The $600-\mathrm{mg} / \mathrm{kg}$ dose induced emesis in 6 out of 7 cats tested. These data were excluded from the statistical analysis.

$(n=6)$ after sertraline. The decrease in neuronal activity produced by each drug was significantly different from placebo, which only reduced firing rate by $2 \pm 2 \%$ $(n=8)$. The inhibitory effect of each SSRI was long lasting, as neuronal activity remained significantly below baseline levels 24 hours after the administration of fluoxetine $(68 \pm 3 \%, n=5)$ or sertraline $(47 \pm 9 \%, n=6)$. To confirm that the suppression of firing produced by these antidepressants was indeed mediated via $5-\mathrm{HT}_{1 \mathrm{~A}}$ autoreceptors, we examined the ability of the selective $5-\mathrm{HT}_{1 \mathrm{~A}}$ receptor antagonist WAY-100635 to restore neuronal activity in animals treated with fluoxetine or sertraline. As shown in Figures 5 and 6, administration of WAY-100635 $(0.2 \mathrm{mg} / \mathrm{kg}$, s.c.) completely reversed the neuronal inhibition observed with both drugs. Moreover, as the antagonist activity of WAY-100635 dissipated over time, neuronal activity gradually declined towards the suppressed preinjection baseline levels (data not shown). Thus, the long-lasting inhibitory effects of both fluoxetine and sertraline are likely to be attributed to increased synaptic availability of serotonin, due to sustained uptake blockade, and subsequent activation of somatodendritic $5-\mathrm{HT}_{1 \mathrm{~A}}$ autoreceptors.

\section{Effect of Acute Intravenous Administration of Hyperforat ${ }^{\circledR}$}

The effect of intravenous administration of cumulative doses of Hyperforat ${ }^{\circledR}(0.5-4 \mathrm{ml})$, a liquid extract of St. John's wort, on the spontaneous activity of serotonergic 


\section{Baseline}

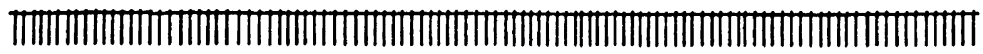

$\operatorname{Jarsin}^{\circledR} 300(600 \mathrm{mg} / \mathrm{kg}$, p.o.)

1 .

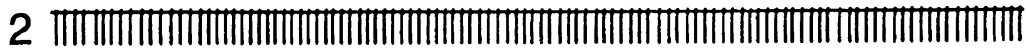

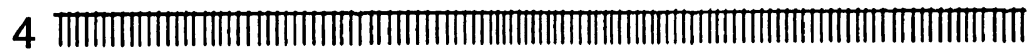

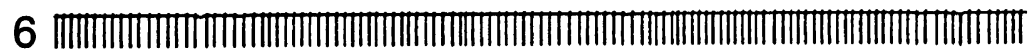

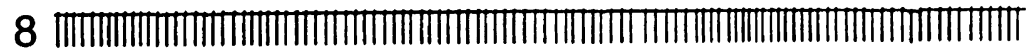

Figure 4. Polygraph event mark traces of unit activity showing the response of a single serotonergic dorsal raphe neuron to acute oral administration of Jarsin ${ }^{\circledR} 300$ $(600 \mathrm{mg} / \mathrm{kg})$. Both the firing rate and discharge pattern of this cell were unaffected by this high dose of hypericum extract. Each pen deflection represents one action potential.

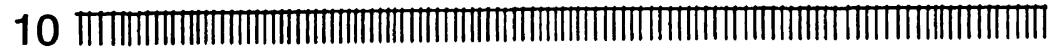

(hr)

\section{$5 \mathrm{sec}$}

dorsal raphe neurons is shown in Figure 7. Hyperfo$\operatorname{rat}{ }^{\circledR}$ had no effect on firing rate. To rule out the possibility of a delayed effect, neuronal activity was monitored for an additional two hours after the last hypericum injection (total dose $=4 \mathrm{ml}$ ). However, we were unable to detect an effect of Hyperforat ${ }^{\circledR}$ on neuronal activity during this time period (data not shown). In contrast, we have previously demonstrated in awake cats that low intravenous doses of fluoxetine or sertraline (i.e., $0.1-0.5 \mathrm{mg} / \mathrm{kg}$ ) strongly suppress the activity of serotonergic dorsal raphe neurons within 2-3 minutes of injection (Fornal et al. 1999; unpublished observations).

\section{Effect of Chronic Oral Administration of Jarsin ${ }^{\circledR} 300$}

The activity of two serotonergic dorsal raphe neurons was monitored during chronic treatment with Jarsin ${ }^{\circledR}$ 300 (150 mg/kg, p.o.; twice daily), one for 17 consecutive days and the other for 21 consecutive days, in two different cats. Computer analyses confirmed the consistent identity of these neurons. Chronic administration of St. John's wort did not result in any pronounced or consistent change in neuronal activity. The average daily firing rates of these cells (expressed as a percentage of baseline) were $92 \%$ and $104 \%$ during week 1 , $90 \%$ and $103 \%$ during week 2 , and $80 \%$ and $99 \%$ during week 3 , respectively.

\section{Effect of Jarsin ${ }^{\circledR} 300$ Pretreatment on the Inhibitory Action of 8-OH-DPAT}

To rule out the possibility that a component of St. John's wort might render serotonergic neurons unresponsive to autoreceptor stimulation (and hence account for the lack of neuronal inhibition observed in the present study), the effect of the direct-acting $5-\mathrm{HT}_{1 \mathrm{~A}}$ receptor agonist 8-OH-DPAT (10 $\mu \mathrm{g} / \mathrm{kg}$, i.v.) was compared before and after acute treatment with Jarsin ${ }^{\circledR} 300$ at the highest dose tolerated ( $300 \mathrm{mg} / \mathrm{kg}$, p.o.). Because previous studies have shown that St. John's wort is slowly absorbed from the gastrointestinal tract (Stock and Hölzl 1991; Brockmöller et al. 1997), a long pretreatment interval was used ( 3 or 5 hours). Since no differences were observed between the two pretreatment times, the data were combined. As shown in Figure 8, systemic administration of 8-OH-DPAT alone (Control) produced a rapid and nearly complete suppression of neuronal activity, followed by a gradual recovery to baseline levels within $120 \mathrm{~min}$. Pretreatment with Jarsin ${ }^{\circledR} 300$ had no appreciable effect on the inhibitory response to 8-OH-DPAT, suggesting that St. John's wort does not interfere with autoreceptor-mediated control of serotonergic neurons.

\section{DISCUSSION}

Most pharmacological treatments for depression affect the brain serotonergic system. Numerous studies have shown that various antidepressant drugs potentiate the action of serotonin at central synapses through a variety of mechanisms (Blier and de Montigny 1994). Current evidence suggests that St. John's wort may act through inhibition of serotonin uptake to produce its antidepressant effect, leading some to call it the "Herbal Prozac". The present study shows that two clinical 

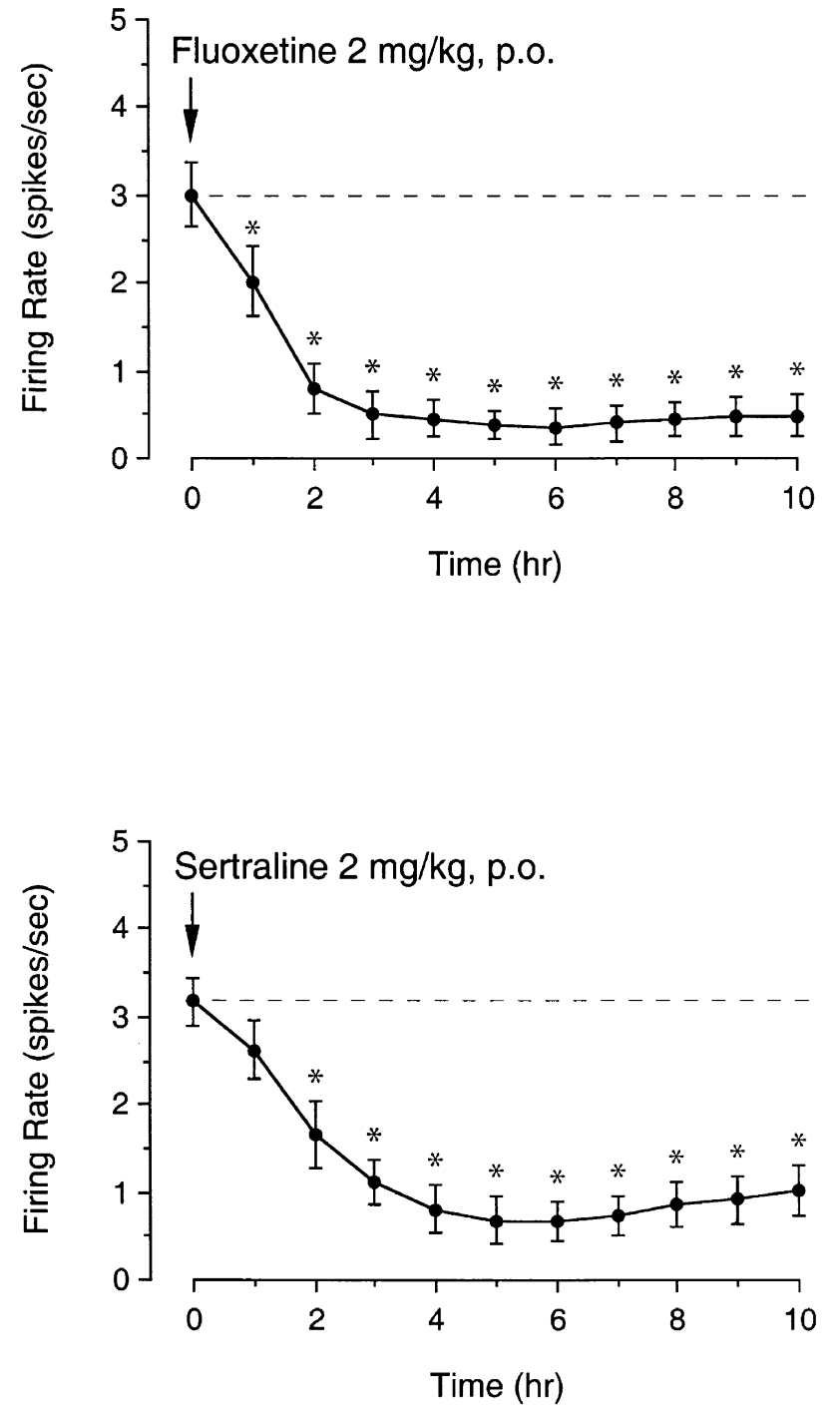

preparations of St. John's wort widely used in the treatment of depression have no appreciable effect on the activity of serotonergic dorsal raphe neurons in freely moving cats. These results contrast with the effects of fluoxetine and sertraline, two popular SSRIs, which markedly depressed the activity of these neurons in the same experimental preparation.

The lack of effect of hypericum extracts cannot be attributed to the use of inadequate doses. Jarsin $\AA 300$ was tested over a wide range of doses $(15-600 \mathrm{mg} / \mathrm{kg}$, p.o.) and invariably failed to affect neuronal activity. The recommended clinical dose of Jarsin ${ }^{\circledR} 300$ is $900 \mathrm{mg} /$ day (Volz 1997; package insert). On a milligram-perkilogram basis, this is roughly equivalent to the lowest dose of Jarsin $® 300$ administered in this study. Our highest dose $(600 \mathrm{mg} / \mathrm{kg})$ is nearly 50 times greater than the normal therapeutic dose. Moreover, since Jarsin ${ }^{\circledR} 300$ was administered as a single dose, rather
WAY -100635
$0.2 \mathrm{mg} / \mathrm{kg}$, s.c.

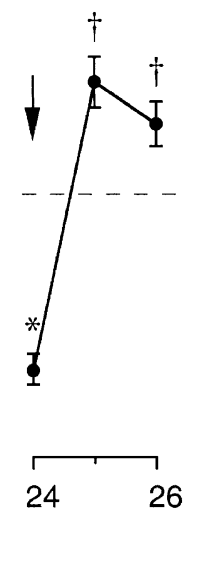

WAY-100635

$0.2 \mathrm{mg} / \mathrm{kg}$, s.c.

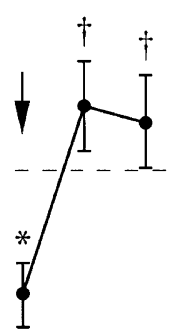

Figure 5. Effects of acute oral administration of $2 \mathrm{mg} / \mathrm{kg}$ of fluoxetine (top panel) or sertraline (bottom panel) on the spontaneous activity of serotonergic dorsal raphe neurons in awake cats. Values are means \pm S.E.M.; $\mathrm{n}=5$ cells for fluoxetine, $n=6$ cells for sertraline. Arrows indicate time of administration. In contrast to the lack of effect observed with St. John's wort, both fluoxetine and sertraline produced a marked and long-lasting inhibition of neuronal activity. The effect of each SSRI was reversed by the selective $5-\mathrm{HT}_{1 \mathrm{~A}}$ receptor antagonist WAY-100635 $(0.2 \mathrm{mg} / \mathrm{kg}$, s.c.). ${ }^{*} p<.05$ versus respective baseline; ${ }^{+} p<.05$ versus respective preinjection level (i.e., 24-h timepoint). than over the course of a day (as done commonly in clinical practice), even higher blood concentrations of the active constituents are likely to have been achieved. Furthermore, doses of hydroalcoholic extracts of hypericum in the range of 50 to $300 \mathrm{mg} / \mathrm{kg}$ p.o. have been shown to exert antidepressant-like effects in several animal models of depression, such as behavioral despair and learned helplessness in rodents (Butterweck et al. 1997; Bhattacharya et al. 1998; Chatterjee et al. 1998; Gobbi et al. 1999; Kumar et al. 1999). Similar doses have also been reported to increase brain 5-hydroxyindole levels (Calapai et al. 1999; Yu 2000), potentiate 5-hydroxytryptophan-induced head-twitches (Bhattacharya et al. 1998), antagonize reserpine-induced behavioral syndrome (Bhattacharya et al. 1998; Kumar et al. 1999), and produce a down-regulation of $\beta$-adrenergic receptors in the rat frontal cortex after subchronic administration (Müller et al. 1997, 1998), a biological marker of antide- 


\section{Baseline \\ (n) \\ Fluoxetine (2 $\mathrm{mg} / \mathrm{kg}$, p.o.)

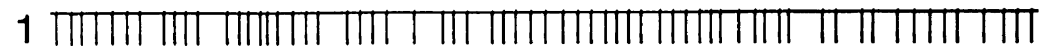

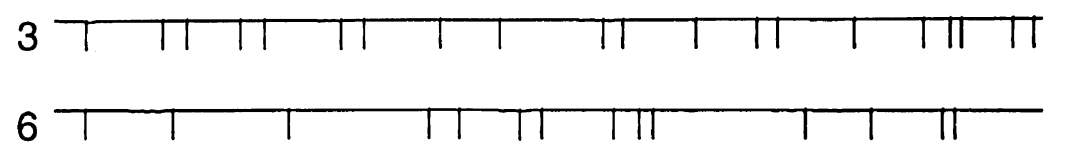

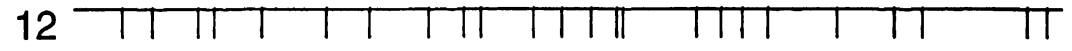

$24 T\|11\| 11\|111\| 11111 \| 11111$

+ WAY-100635 (0.2 mg/kg, s.c.)
Figure 6. Polygraph event mark traces of unit activity showing the response of a single serotonergic dorsal raphe neuron to acute oral administration of fluoxetine $(2 \mathrm{mg} / \mathrm{kg}$ ). Note the marked slowing of neuronal activity and the loss of regular discharge after fluoxetine. Both of these effects were reversed by WAY-100635 (0.2 $\mathrm{mg} / \mathrm{kg}$, s.c.). Each pen deflection represents one action potential.

0.5

(hr)

5 sec

pressant efficacy. Similarly, Hyperforat ${ }^{\circledR}(0.5-4 \mathrm{ml}$, i.v. $)$ had no appreciable effect on firing rate. These doses also exceed the recommended clinical dose $(1-2 \mathrm{ml} /$ day) by as much as 35 to 75 -fold, based on body weight. However, it is possible that the bioavailability of St. John's wort extracts may be different in cats compared to humans.

In contrast to hypericum extracts, the SSRIs sertraline and fluoxetine produced a marked inhibition of serotonergic neuronal activity. The dose of sertraline and fluoxetine used in the present study $(2 \mathrm{mg} / \mathrm{kg}$, p.o.) is approximately 1-2 and 4-7 times the usual clinical dose in humans, respectively (Baldessarini 1996). The prolonged inhibitory action $(>24 \mathrm{~h}$ ) of fluoxetine and sertraline is consistent with their pharmacokinetic properties. Both drugs have long elimination half-lives and significantly accumulate during chronic daily administration (van Harten 1993; Hyttel 1994). Although sertraline is more potent than fluoxetine in blocking serotonin uptake both in vitro and in vivo (Koe et al. 1983; van Harten 1993; Hyttel 1994), its oral bioavailability is less than that for fluoxetine (van Harten 1993). Sertraline is extensively metabolized to an inactive compound (desmethylsertraline) (Sprouse et al. 1996), whereas fluoxetine is converted to norfluoxetine, a potent and selective serotonin reuptake inhibitor (Wong et al. 1995). This might explain why fluoxetine had a somewhat greater effect on neuronal activity than sertraline at identical oral doses. In a recent comparative study, both fluoxetine $\left(\mathrm{IC}_{50}=10.4 \mathrm{nM}\right)$ and sertraline $\left(\mathrm{IC}_{50}=2.1 \mathrm{nM}\right)$ were found to be considerably more potent in blocking serotonin uptake into mouse synaptosomes than hyperforin
$\left(\mathrm{IC}_{50}=1357 \mathrm{nM}\right)$, the putative active ingredient of St. John's wort extracts (Singer et al. 1999).

Neurochemical studies have shown that antidepressant drugs that inhibit the serotonin transporter (e.g., SSRIs and certain tricyclics) preferentially increase the concentration of extracellular serotonin in the midbrain raphe, presumably because this region has the highest density of serotonin uptake sites in the brain (Adell and Artigas 1991; Invernizzi et al. 1992; Artigas 1993; Hervás and Artigas 1998). The increase in raphe serotonin leads to an inhibition of serotonergic neuronal activity through enhanced activation of somatodendritic 5- $\mathrm{HT}_{1 \mathrm{~A}}$ autoreceptors (Blier and de Montigny 1994). The resulting decrease in serotonin release counteracts the ability of these drugs to potentiate the action of serotonin at postsynaptic target sites (e.g., frontal cortex), and thus may account for the delayed onset of the therapeutic response. Upon chronic administration, tolerance develops to the inhibitory action of these drugs on neuronal activity, due to a desensitization of 5- $\mathrm{HT}_{1 \mathrm{~A}}$ autoreceptors (Blier et al. 1990; Czachura and Rasmussen 2000). The resumption of serotonergic neuronal activity during sustained uptake inhibition is thought to play a critical role in the ability of these drugs to produce an overall enhancement of serotonin neurotransmission, which may underlie the therapeutic effect (Blier and de Montigny 1994). Current pharmacological strategies aimed at accelerating the clinical effects of SSRIs have focused on preventing the inhibitory feedback action of serotonin, thus mimicking the functional consequences seen after autoreceptor desensitization (Artigas et al. 1996; Romero et al. 1997). The fact that St. John's wort does not activate this negative feed- 

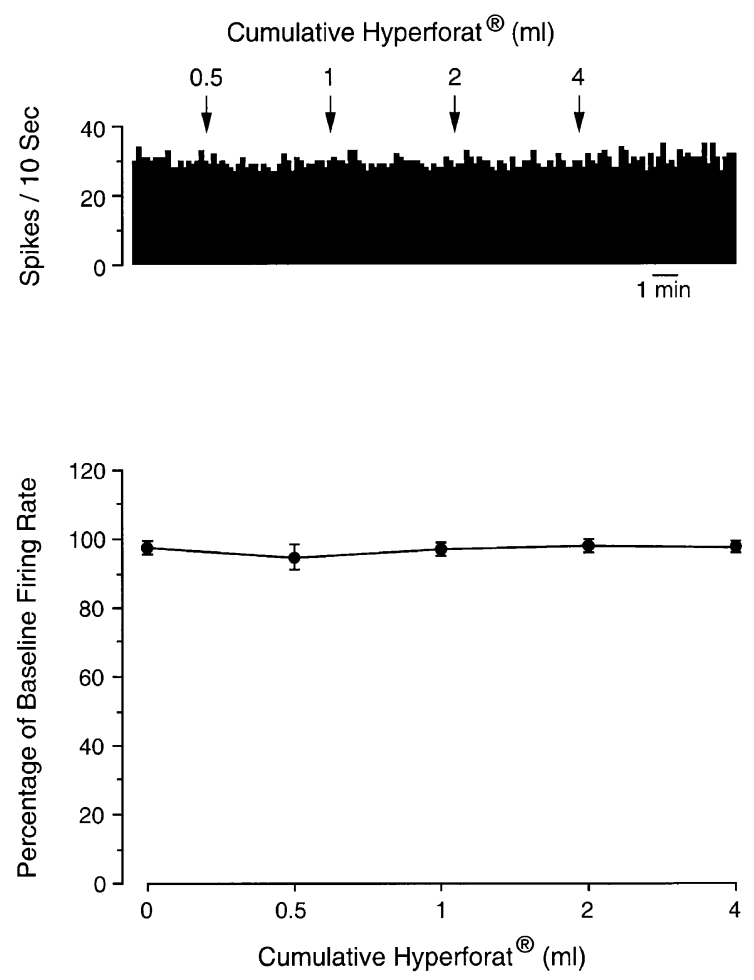

Figure 7. Effects of acute intravenous administration of cumulative doses $(0.5-4.0 \mathrm{ml})$ of Hyperforat ${ }^{\circledR}$ on the spontaneous activity of serotonergic dorsal raphe neurons in awake cats. Top panel: Integrated firing rate histogram showing the response of a representative cell to Hyperforat ${ }^{\circledR}$. Arrows denote time of injections. Bottom panel: Cumulative dose-response curve. Values are means \pm S.E.M.; $\mathrm{n}=6$ cells. This liquid extract of St. John's wort had no significant effect on neuronal activity.

back mechanism, even at high doses, suggests that it does not enhance extracellular serotonin levels in the brain, at least not in the vicinity of presynaptic $5-\mathrm{HT}_{1 \mathrm{~A}}$ autoreceptors. Thus, while several studies have reported that hypericum extracts can inhibit serotonin uptake in cell cultures (Neary and Bu 1999) and in synaptosomal preparations (Perovic and Müller 1995; Müller et al. 1997, 1998; Chatterjee et al. 1998), the concentrations required in vivo for such activity may not be achieved at clinically relevant doses. Consistent with this idea, systemic administration of St. John's wort $(1000 \mathrm{mg} / \mathrm{kg}$, p.o.) had no effect on basal extracellular concentrations of serotonin in the rat hippocampus (Di Matteo 2000).

It may be informative to compare the concentrations of hypericum needed for in vitro activity with those achieved in vivo. Pharmacokinetic experiments in humans have shown that after a single therapeutic dose of hypericum extract (300 mg, 5\% hyperforin), plasma hyperforin levels reach a peak of about $280 \mathrm{nM}$, with steady-state plasma levels estimated to be approximately $180 \mathrm{nM}$ after a standard treatment regimen (i.e., $300 \mathrm{mg}$, t.i.d.)(Biber et

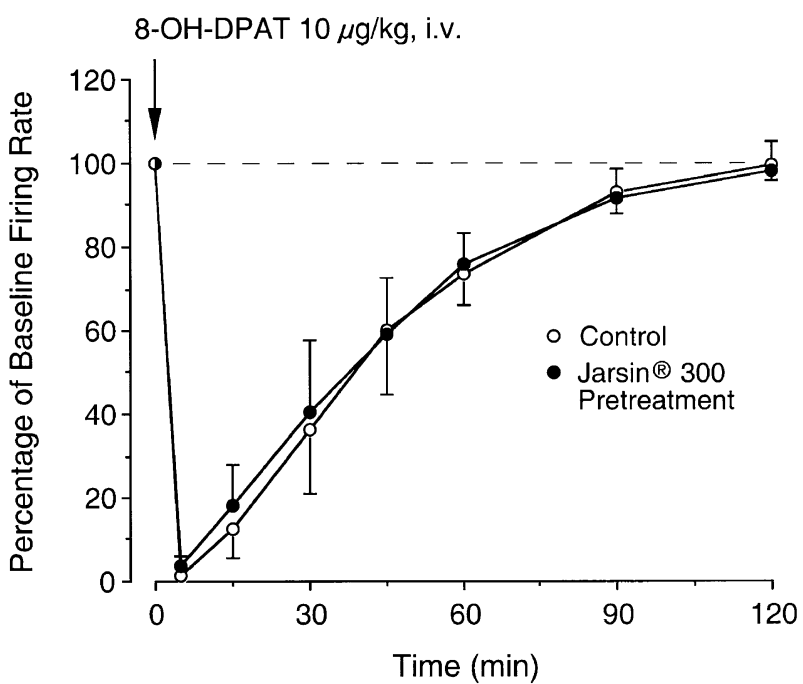

Figure 8. Response of serotonergic dorsal raphe neurons to an intravenous challenge dose $(10 \mu \mathrm{g} / \mathrm{kg})$ of the $5-\mathrm{HT}_{1 \mathrm{~A}}$ receptor agonist 8-OH-DPAT before (Control) and after Jarsin ${ }^{\circ} 300$ (300 mg/kg, p.o.; 3-h or 5-h pretreatment, 3 cells each). Arrow indicates time of injection. Values are means \pm S.E.M.; $\mathrm{n}=6$ cells. 8-OH-DPAT significantly suppressed neuronal activity from $5 \mathrm{~min}$ to $60 \mathrm{~min}$ after injection, compared to respective preinjection baseline levels. Pretreatment with Jarsin $® 300$ had no effect on the inhibitory action of 8-OH-DPAT, indicating that St. John's wort does not interfere with $5-\mathrm{HT}_{1 \mathrm{~A}}$ autoreceptor function. The preinjection 8-OH-DPAT baseline firing rates of these neurons were $3.08 \pm 0.31$ spikes $/ \mathrm{sec}$ in the Control (no pretreatment) condition and $3.15 \pm 0.39$ spikes $/$ sec after Jarsin $₫ 300$ pretreatment. The $8-\mathrm{OH}-\mathrm{DPAT}$ injections were separated by at least 5 hours.

al. 1998). In rats, peak plasma levels of about $690 \mathrm{nM}$ of hyperforin were found after oral administration of 300 $\mathrm{mg} / \mathrm{kg}$ of the same hypericum extract (Biber et al. 1998). Reported $\mathrm{IC}_{50}$ values for hyperforin as an inhibitor of synaptosomal uptake of serotonin have ranged from $120 \mathrm{nM}$ to 3,300 nM (Müller et al. 1998; Gobbi et al. 1999; Singer et al. 1999; Jensen et al. 2001). Thus, according to the results of some of the above studies (Müller et al. 1998; Jensen et al. 2001), the blood levels of hyperforin observed in both rats and humans after standard doses of hypericum extract are within the concentration range needed to inhibit serotonin uptake in vitro. However, it is not known to what extent hyperforin crosses the blood-brain barrier. Interestingly, hypericin, once thought to be the main active ingredient of St. John's wort, was not detected in the cerebrospinal fluid of nonhuman primates after intravenous administration of extremely large doses ( $>2 \mathrm{mg} /$ $\mathrm{kg}$ ), suggesting that the compound does not cross the blood-brain barrier to any appreciable extent (Fox et al. 2001). However, since hyperforin is more lipophilic than hypericin, it may penetrate into the brain more readily 
than hypericin. Thus, it will be important to quantify the levels of this substance in the brain and to determine whether it is capable of inhibiting serotonin uptake in vivo, since this has not been demonstrated yet for hypericum or any of its constituents.

The failure of St. John's wort to depress the singleunit activity of serotonergic neurons, like some classical antidepressants (fluoxetine and sertraline), cannot be attributed to an impairment of autoreceptor function. Pretreatment with St. John's wort had no effect on the suppression of serotonergic neurons produced by 8-OH-DPAT, a highly selective $5-\mathrm{HT}_{1 \mathrm{~A}}$ agonist. The inhibitory action of systemically administered 8-OH-DPAT is generally attributed to stimulation of somatodendritic $5-\mathrm{HT}_{1 \mathrm{~A}}$ autoreceptors, although an involvement of postsynaptic $5-\mathrm{HT}_{1 \mathrm{~A}}$ receptors can not be excluded (Ceci et al. 1994; Hajós et al. 1999). Thus, while crude extracts of St. John's wort may display some affinity for the $5-\mathrm{HT}_{1}$ receptor (Cott 1997), this property does not appear to influence the activity of serotonergic neurons. In addition, although St. John's wort has been shown to inhibit the uptake of norepinephrine and dopamine in vitro, it is unlikely that such a blockade would interfere with the ability of serotonin reuptake inhibitors to suppress neuronal activity in vivo. This is supported in part by the fact that dual serotonin/norepinephrine reuptake inhibitors, such as duloxetine and venlafaxine, potently inhibit the firing rate of serotonergic neurons in both the anesthetized and freely moving animal (Gartside et al. 1997; Béique et al. 1999; Bjorvatn et al. 2000).

The conclusion that St. John's wort does not act in a manner similar to that of classical serotonin reuptake inhibitors is supported by recent findings. Crude hypericum preparations, as well as hyperforin itself (the purported active constituent of St. John's wort), have no appreciable affinity for the serotonin-uptake binding site labeled by $\left[{ }^{3} \mathrm{H}\right]$ citalopram or $\left[{ }^{3} \mathrm{H}\right]$ paroxetine (Gobbi et al. 1999; Singer et al. 1999), indicating that they do not interact similarly with the serotonin transport mechanism. The apparent inhibition of serotonin uptake observed with hypericum and/or hyperforin in vitro may be due to an increase in free intracellular sodium concentrations (Singer et al. 1999) or to a reserpine-like releasing action (Gobbi et al. 1999), as opposed to true blockade of the serotonin uptake mechanism. Such nonselective effects might explain why hypericum extracts (and hyperforin) appear to block the synaptosomal uptake of multiple neurotransmitters, including serotonin, norepinephrine, dopamine, $\gamma$-aminobutyric acid and L-glutamate (Chatterjee et al. 1998; Singer et al. 1999; Wonnemann et al. 2000). Furthermore, unlike classical serotonin reuptake inhibitors, hypericum extracts do not inhibit the turnover or metabolism of serotonin in the brain after systemic application (Calapai et al. 1999; Gobbi et al. 1999; Yu 2000), nor do they increase the concentration of extracellular serotonin, as measured by intracerebral microdialysis (Di Matteo et al. 2000). In fact, neurochemical studies have shown that St. John's wort can actually increase serotonin turnover and brain concentrations of 5-hydroxyindoleacetic acid (5-HIAA), the major metabolite of serotonin (Calapai et al. 1999; Yu 2000). This latter finding would also argue against any significant MAO-inhibiting properties of St. John's wort in vivo, since such inhibition prevents the formation of 5-HIAA.

In summary, while St. John's wort appears to be a promising phytomedicine for the treatment of depression, its mode of action remains unknown. Our results suggest that St. John's wort is not likely to act via inhibition of serotonin uptake, as currently believed, or by any other means of increasing brain serotonin. Moreover, since St. John's wort is nearly equipotent in blocking the uptake of serotonin, norepinephrine and dopamine in vitro (Müller et al. 1997, 1998; Chatterjee et al. 1998; Neary and Bu 1999), our results also suggest that St. John's wort is not likely to inhibit the uptake of brain catecholamines in vivo, at therapeutic doses. Therefore, the antidepressant action of St. John's wort may not be related at all to monoamine uptake inhibition. Additional studies are needed to identify and characterize the constituents responsible for the antidepressant activity of St. John's wort. As a results of this research, new and improved antidepressant drugs may be developed in the future.

\section{ACKNOWLEDGMENTS}

We thank Dr. Georg Jückel (Department of Psychiatry, Ludwig Maximilians University, Munich, Germany) for kindly supplying us with the hypericum extracts used in this study. We also thank Eli Lilly, Pfizer, and Wyeth Research for their generous gifts of fluoxetine, sertraline, and WAY-100635, respectively. This work was supported by Grant MH-23433 from the National Institute of Mental Health.

\section{REFERENCES}

Adell A, Artigas F (1991): Differential effects of clomipramine given locally or systemically on extracellular 5HT in raphe nuclei and frontal cortex. An in vivo brain dialysis study. Naunyn Schmiedebergs Arch Pharmacol 343:237-244

Aghajanian GK, VanderMaelen CP (1986): Specific systems of the reticular core: serotonin. Handb Physiol 4:237-256

Aghajanian GK, Wang RY (1978): Physiology and pharmacology of central serotonergic neurons. In Lipton MA, Di Mascio A, Killam KF (eds), Psychopharmacology: A Generation of Progress. New York, Raven Press, pp 171-183

Artigas F (1993): 5-HT and antidepressants: new views from microdialysis studies. Trends Pharmacol Sci 14:262 
Artigas F, Romero L, de Montigny C, Blier P (1996): Acceleration of the effect of selected antidepressant drugs in major depression by $5-\mathrm{HT}_{1 \mathrm{~A}}$ antagonists. Trends Neurosci 19:378-383

Baldessarini R (1996): Drugs and the treatment of psychiatric disorders. Depression and mania. In Hardman JG, Limbird LE, Molinoff PB, Ruddon RW, Gilman AG (eds), Goodman \& Gilman's The Pharmacological Basis of Therapeutics, 9th ed., New York, McGraw-Hill, pp 431-459

Béïque JC, de Montigny C, Blier P, Debonnel G (1999): Venlafaxine: discrepancy between in vivo 5-HT and NE reuptake blockade and affintity for reuptake sites. Synapse 32:198-211

Bennett Jr DA, Phun L, Polk JF, Voglino SA, Zlotnik V, Raffa RB (1998): Neuropharmacology of St. John's Wort (Hypericum). Ann Pharmacother 32:1201-1208

Bhattacharya SK, Chakrabarti A, Chatterjee SS (1998): Activity profiles of two hyperforin-containing hypericum extracts in behavioral models. Pharmacopsychiatry 31(Suppl 1):22-29

Biber A, Fischer H, Römer A, Chatterjee SS (1998): Oral bioavailability of hyperforin from hypericum extracts in rats and human volunteers. Pharmacopsychiatry 31 (Suppl 1):36-43

Bladt S, Wagner H (1994): Inhibition of MAO by fractions and constituents of hypericum extract. J Geriatr Psychiatry Neurol 7(Suppl 1):S57-S59

Blier P, de Montigny C (1994): Current advances and trends in the treatment of depression. Trends Pharmacol Sci 15:220-226

Blier P, de Montigny C, Chaput Y (1990): A role for the serotonin system in the mechanism of action of antidepressant treatments: preclinical evidence. J Clin Psychiatry 51(Suppl 4):14-20

Bjorvatn B, Fornal CA, Martín FJ, Metzler CW, Jacobs BL (2000): Venlafaxine and its interaction with WAY 100635: effects on serotonergic unit activity and behavior in cats. Eur J Pharmacol 404:121-132

Brockmöller J, Reum T, Bauer S, Kerb R, Hübner W-D, Roots I (1997): Hypericin and pseudohypericin: pharmacokinetics and effects on photosensitivity in humans. Pharmacopsychiatry 30 (Suppl 2):94-101

Bunk S (1999): St. John's wort set for U.S. clinical trials. The Scientist 13:10

Butterweck V, Wall A, Liefländer-Wulf U, Winterhoff $H$, Nahrstedt A (1997): Effects of the total extract and fractions of Hypericum perforatum in animal assays for antidepressant activity. Pharmacopsychiatry 30(Suppl 2):117-124

Calapai G, Crupi A, Firenzuoli F, Costantino G, Inferrera G, Campo GM, Caputi AP (1999): Effects of Hypericum perforatum on levels of 5-hydroxytryptamine, noradrenaline and dopamine in the cortex, diencephalon and brainstem of the rat. J Pharm Pharmacol 51:723-728

Ceci A, Baschirotto A, Borsini F (1994): The inhibitory effect of 8-OH-DPAT on the firing activity of dorsal raphe serotoninergic neurons in rats is attenuated by lesion of the frontal cortex. Neuropharmacology 33:709-713

Chatterjee SS, Bhattacharya SK, Wonnemann M, Singer A, Müller WE (1998): Hyperforin as a possible antidepressant component of hypericum extracts. Life Sci 63:499-510
Constantine GH, Karchesy J (1998): Variations in hypericin concentrations in Hypericum perforatum L. and commercial products. Pharm Biol 36:365-367

Cott JM (1997): In vitro receptor binding and enzyme inhibition by Hypericum perforatum extract. Pharmacopsychiatry 30(Suppl 2):108-112

Czachura JF, Rasmussen K (2000): Effects of acute and chronic administration of fluoxetine on the activity of serotonergic neurons in the dorsal raphe nucleus of the rat. Naunyn Schmiedebergs Arch Pharmacol 362:266-275

Demisch L, Hölzl J, Gollnik B, Kaczmarczyk P (1989): Identification of selective MAO-type-A inhibitors in Hypericum perforatum L. (Hyperforat ${ }^{\circledR}$ ). Pharmacopsychiatry 22:194

Di Matteo V, Di Giovanni G, Di Mascio M, Esposito E (2000): Effect of acute administration of Hypericum perforatum$\mathrm{CO}_{2}$ extract on dopamine and serotonin release in the rat central nervous system. Pharmacopsychiatry 33:14-18

Ernst E, Rand JI, Barnes J, Stevinson C (1998): Adverse effects profile of the herbal antidepressant St. John's wort (Hypericum perforatum L.). Eur J Clin Pharmacol 54:589-594

Fornal CA, Jacobs BL (1988): Physiological and behavioral correlates of serotonergic single-unit activity. In Osborne NN, Hamon M (eds), Neuronal Serotonin. New York, John Wiley \& Sons, pp 305-345

Fornal CA, Martín FJ, Metzler CW, Jacobs BL (1999): Pindolol, a putative 5-hydroxytryptamine ${ }_{1 \mathrm{~A}}$ antagonist, does not reverse the inhibition of serotonergic neuronal activity induced by fluoxetine in awake cats: comparison to WAY-100635. J Pharmacol Exp Ther 291:220-228

Fornal CA, Metzler CW, Gallegos RA, Veasey SC, McCreary AC, Jacobs BL (1996): WAY-100635, a potent and selective 5-hydroxytryptamine ${ }_{1 \mathrm{~A}}$ antagonist, increases serotonergic neuronal activity in behaving cats: comparison with (S)-WAY-100135. J Pharmacol Exp Ther 278:752-762

Fox E, Murphy RF, McCully CL, Adamson PC (2001): Plasma pharmacokinetics and cerebrospinal fluid penetration of hypericin in nonhuman primates. Cancer Chemother Pharmacol 47:41-44

Gartside SE, Umbers V, Sharp T (1997): Inhibition of 5-HT cell firing in the DRN by non-selective 5 -HT reuptake inhibitors: studies on the role of $5-\mathrm{HT}_{1 \mathrm{~A}}$ autoreceptors and noradrenergic mechanisms. Psychopharmacology 130:261-268

Gaster B, Holroyd J (2000): St John's wort for depression. A systematic review. Arch Intern Med 160:152-156

Gobbi M, Valle FD, Ciapparelli C, Diomede L, Morazzoni P, Verotta L, Caccia S, Cervo L, Mennini T (1999): Hypericum perforatum L. extract does not inhibit 5-HT transporter in rat brain cortex. Naunyn Schmiedebergs Arch Pharmacol 360:262-269

Hajós M, Hajós-Korcsok E, Sharp T (1999): Role of the medial prefrontal cortex in $5-\mathrm{HT}_{1 \mathrm{~A}}$ receptor-induced inhibition of 5-HT neuronal activity in the rat. Br J Pharmacol 126:1741-1750

Hervás I, Artigas F (1998): Effect of fluoxetine on extracellular 5-hydroxytryptamine in rat brain. Role of 5-HT autoreceptor. Eur J Pharmacol 358:9-18

Hippius H (1998): St John's wort (Hypericum perforatum) - a herbal antidepressant. Curr Med Res Opin 14:171-184

Hyttel J (1994): Pharmacological characterization of selective 
serotonin reuptake inhibitors (SSRIs). Int Clin Psychopharmacol 9(Suppl 1):19-26

Invernizzi R, Belli S, Samanin R (1992): Citalopram's ability to increase the extracellular concentrations of serotonin in the dorsal raphe prevents the drug's effect in the frontal cortex. Brain Res 584:322-324

Jacobs BL, Azmitia EC (1992): Structure and function of the brain serotonin system. Physiol Rev 72:165-229

Jacobs BL, Gannon PJ, Azmitia EC(1984): Atlas of serotonergic cell bodies in the cat brainstem: an immunocytochemical analysis. Brain Res Bull 13:1-31

Jensen AG, Hansen SH, Nielsen EØ (2001): Adhyperforin as a contributor to the effect of Hypericum perforatum L. in biochemical models of antidepressant activity. Life Sci 68:1593-1605

Josey ES, Tackett RL (1999): St. John's wort: a new alternative for depression? Int J Clin Pharmacol Ther 37:111-119

Kim HL, Streltzer J, Goebert D (1999): St. John's wort for depression. A meta-analysis of well-defined clinical trials. J Nerv Ment Dis 187:532-538

Koe BK, Weissman A, Welch WM, Browne RG (1983): Sertraline, 1S,4S-N-methyl-4-(3,4-dichlorophenyl)-1,2,3,4tetrahydro-1-naphthylamine, a new uptake inhibitor with selectivity for serotonin. J Pharmacol Exp Ther 226: 686-700

Kumar V, Singh PN, Jaiswal AK, Bhattacharya SK (1999): Antidepressant activity of Indian Hypericum perforatum Linn in rodents. Indian J Exp Biol 37:1171-1176

Kurth H, Spreemann R (1998): Phytochemical characterization of various St. John's Wort extracts. Adv Ther 15:117-128

Laakmann G, Schüle C, Baghai T, Kieser M (1998): St. John's wort in mild to moderate depression: the relevance of hyperforin for the clinical efficacy. Pharmacopsychiatry 31(Suppl 1):54-59

Linde K, Ramirez G, Mulrow CD, Pauls A, Weidenhammer W, Melchart D (1996): St John's wort for depression-an overview and meta-analysis of randomised clinical trials. Br Med J 313:253-258

Liu FF, Ang CYW, Heinze TM, Rankin JD, Beger RD, Freeman JP, Lay Jr JO (2000): Evaluation of major active components in St. John's Wort dietary supplements by high-performance liquid chromatography with photodiode array detection and electrospray mass spectrometric confirmation. J Chromatogr A 888:85-92

Maes M, Meltzer HY (1995): The serotonin hypothesis of major depression. In FE Bloom, Kupfer DJ (eds), Psychopharmacology: The Fourth Generation of Progress. New York, Raven Press, pp 933-944

Müller WE, Kasper S (1997): Editorial. Pharmacopsychiatry 30(Suppl 2):71

Müller WE, Rolli M, Schäfer C, Hafner U (1997): Effects of hypericum extract (LI 160) in biochemical models of antidepressant activity. Pharmacopsychiatry 30(Suppl 2):102-107

Müller WE, Singer A, Wonnemann M, Hafner U, Rolli M, Schafer C (1998): Hyperforin represents the neurotransmitter reuptake inhibiting constituent of hypericum extract. Pharmacopsychiatry 31(Suppl 1):16-21
Nathan P (1999): The experimental and clinical pharmacology of St John's Wort (Hypericum perforatum L.). Mol Psychiatry 4:333-338

Neary JT, Bu Y (1999): Hypericum LI 160 inhibits uptake of serotonin and norepinephrine in astrocytes. Brain Res 816:358-363

Perovic S, Müller WEG (1995): Pharmacological profile of hypericum extract. Effect on serotonin uptake by postsynaptic receptors. Arzneimittelforschung 45:1145-1148

Romero L, Casanovas JM, Hervás I, Cortés R, Artigas F (1997): Strategies to optimize the antidepressant action of selective serotonin reuptake inhibitors. In Skolnick P (ed), Antidepressants: New Pharmacological Strategies. Totowa, Humana Press, pp 1-33

Singer A, Wonnemann M, Müller WE (1999): Hyperforin, a major antidepressant constituent of St. John's Wort, inhibits serotonin uptake by elevating free intracellular $\mathrm{Na}^{+1}$. J Pharmacol Exp Ther 290:1363-1368

Snider RS, Niemer WT (1970): A Stereotaxic Atlas of the Cat Brain. Chicago, The University of Chicago Press

Sprouse JS, Aghajanian GK (1986): (-)-Propranolol blocks the inhibition of serotonergic dorsal raphe cell firing by 5$\mathrm{HT}_{1 \mathrm{~A}}$ selective agonists. Eur J Pharmacol 128:295-298

Sprouse JS, Clarke T, Reynolds L, Heym J, Rollema H (1996): Comparison of the effects of sertraline and its metabolite desmethysertraline on blockade of central 5-HT reuptake in vivo. Neuropsychopharmacology 14:225-231

Stevinson C, Ernst E (1999): Hypericum for depression. An update of the clinical evidence. Eur Neuropsychopharmacol 9:501-505

Stock S, Hölzl J (1991): Pharmacokinetic test of [ $\left.{ }^{14} \mathrm{C}\right]$-labelled hypericin and pseudohypericin from Hypericum perforatum and serum kinetics of hypericin in man. Planta Med 57(Suppl 2):A61-A62

Thiede H-M, Walper A (1994): Inhibition of MAO and COMT by hypericum extracts and hypericin. J Geriatr Psychiatry Neurol 7(Suppl 1):S54-S56

van Harten J (1993): Clinical pharmacokinetics of selective serotonin reuptake inhibitors. Clin Pharmacokinet 24:203-220

Vitiello B (1999): Hypericum perforatum extracts as potential antidepressants. J Pharm Pharmacol 51:513-517

Volz H-P (1997): Controlled clinical trials of hypericum extracts in depressed patients-an overview. Pharmacopsychiatry 30(Suppl 2):72-76

Wheatley D (1998): Hypericum extract. Potential in the treatment of depression. CNS Drugs 9:431-440

Wong DT, Bymaster FP, Engleman EA (1995): Prozac (fluoxetine, Lilly 110140), the first selective serotonin uptake inhibitor and an antidepressant drug: twenty years since its first publication. Life Sci 57:411-441

Wonnemann M, Singer A, Müller WE (2000): Inhibition of synaptosomal uptake of ${ }^{3} \mathrm{H}$-L-glutamate and ${ }^{3} \mathrm{H}-\mathrm{GABA}$ by hyperforin, a major constituent of St. John's Wort. The role of amiloride sensitive sodium conductive pathways. Neuropsychopharmacology 23:188-197

Yu PH (2000): Effect of the Hypericum perforatum extract on serotonin turnover in the mouse brain. Pharmacopsychiatry 33:60-65 